OPEN ACCESS

Edited by:

Maurice Millet,

University of Strasbourg, France

Reviewed by:

Maria De Fatima Andrade,

University of São Paulo, Brazil

Delhomme Olivier,

University of Lorraine, France

*Correspondence:

Juan F. Franco

jffranco@uniandes.edu.co

Specialty section: This article was submitted to Air Pollution,

a section of the journal

Frontiers in Environmental Science

Received: 20 September 2016 Accepted: 09 November 2016

Published: 25 November 2016

Citation:

Franco JF, Segura JF and Mura I (2016) Air Pollution alongside Bike-Paths in Bogotá-Colombia.

Front. Environ. Sci. 4:77. doi: 10.3389/fenvs.2016.00077

\section{Air Pollution alongside Bike-Paths in Bogotá-Colombia}

\author{
Juan F. Franco ${ }^{1 *}$, Julián F. Segura ${ }^{2}$ and Ivan Mura $^{3}$ \\ ${ }^{1}$ Group of Studies on Urban and Regional Sustainability, School of Engineering, Universidad de los Andes, Bogotá, Colombia, \\ ${ }^{2}$ Research Group on Environmental Management, School of Engineering, Universidad EAN, Bogotá, Colombia, ${ }^{3}$ COPA \\ Research Group, Department of Industrial Engineering, School of Engineering, Universidad de los Andes, Bogotá, Colombia
}

The study we present in this paper aims at characterizing the range of fine particulate matter $\left(\mathrm{PM}_{2.5}\right)$ and black carbon $(\mathrm{BC})$ concentrations to which bike-path users in Bogotá are exposed to. Using a bike equipped with a DustTrak and a micro-aethalometer we measured $\mathrm{PM}_{2.5}$ and $\mathrm{BC}$ concentration levels along bike-paths corridors, during weekdays and weekends. Experiments were conducted in fours streets, representing four typical configurations of bike-paths in the city. Traffic data for workdays was also available from local mobility authority. Results indicate that bike-paths users in Bogotá are exposed to air pollution levels far exceeding the threshold values established as potentially dangerous for human health. Average concentrations for $\mathrm{PM}_{2.5}$ ranged between 80 and $136 \mathrm{ug} / \mathrm{m}^{3}$ in workdays and between 30 and $72 \mathrm{ug} / \mathrm{m}^{3}$ in weekends. $\mathrm{BC}$ mean concentrations were between 16 and $38 \mu \mathrm{g} / \mathrm{m}^{3}$ during workdays and in the range $10-32 \mu \mathrm{g} / \mathrm{m}^{3}$ during weekends. A statistically significant difference exists in the levels of pollutants concentrations measured during workdays and weekends for all the considered bike paths. According to our results, both traffic volume and diffusions conditions, which are affected by many factors including street geometry, affect bike-path user's exposure levels. Taking into account the important role that bicycling is playing as an alternative transport mode in Latin American cities, we consider these results provide useful insights to increase the appreciation of the excessive bikers' exposure to air pollution in Bogotá. Moreover, these findings contribute with technical elements that should lead to the inclusion of air quality variable when designing and planning sustainable urban mobility infrastructures.

\section{Keywords: particulate matter, black carbon, bike infrastructure, urban planning, sustainable transportation}

\section{INTRODUCTION}

Over the last decade, Bogotá has been recognized for its large bike-dedicated infrastructure. The city is currently endowed with more than $450 \mathrm{~km}$ of bike-paths and near 600 thousand trips are made by bicycle, accounting for $6 \%$ of the total daily trips (Ríos et al., 2015). These figures make Bogotá the Latin-American city with the largest number of kilometers of bike-lines, almost as the double as Sao Paulo, Ciudad de México, and Santiago de Chile (Baumann et al., 2013). The initial motivation for cycling in Colombian cities was primary related to economic reasons. Many people simply could not afford paying the everyday cost of public transportation. Moreover, there has been a relatively recent initiative for encouraging bicycle usage as a sustainable transport mode to face to the critical urban mobility conditions, while fostering healthier life-styles, and increasing the level of physical activity. 
However, most of the bike-paths in Bogotá are located alongside busy roads, where cyclists are experimenting air quality conditions that may not be adequate for performing such physical activity. A question arises as to whether biking under such conditions may overcome the benefits of cycling. This is even more of concern, since Bogotá has been listed among the most polluted cities in Latin America (WHO, 2016). Elevated concentrations of pollutants, especially respirable particulate matter $\left(\mathrm{PM}_{10}\right)$, represent a constant issue (Franco $\mathrm{R}, 2012$ ). According to the data from the city's air quality monitoring network, in 2013 the annual $\mathrm{PM}_{10}$ average concentration in the city ranged between 32 and $81 \mu \mathrm{g} / \mathrm{m}^{3}$, in the northern and western regions of the city, respectively (SDA, 2014). In some areas of the city, both WHO reference threshold values (annual-20 $\mu \mathrm{g} / \mathrm{m}^{3}$ and $24-\mathrm{h}-50 \mu \mathrm{g} / \mathrm{m}^{3}$ ) and national standards (annual-50 $\mu \mathrm{g} / \mathrm{m}^{3}$ and $24-\mathrm{h}-100 \mu \mathrm{g} / \mathrm{m}^{3}$ ), are regularly exceeded.

This is a matter of concern, since inhalation of particulate matter has been related to various diseases. Many epidemiological studies have provided evidence of association between the exposure to PM and asthma, bronchitis and chronic obstructive pulmonary disease, as well as cardiovascular diseases (van Berlo et al., 2012). Closeness to highly polluted locations, such as heavy traffic streets, reveals to be a risk factor for respiratory complications in vulnerable population, leading to reduction of pulmonary function (Peters et al., 1999; Fritz and Herbarth, 2001; Kim et al., 2004; Calderón-Garcidueñas et al., 2006; Ni et al., 2015).

Much like in other Latin-American cities, transportation is one of the most important sources of air pollution in Bogotá (WMO, 2012). According to the city emission inventory, $65 \%$ of $\mathrm{PM}_{10}$ is generated by mobile sources (SDA, 2011), in particular from public transport and freight vehicles using diesel fuel. Although this vehicular category represents $<5 \%$ of the actual fleet, it emits more than $60 \%$ of the PM associated to mobile sources in the city (SDA, 2011). In terms of exposure, mobile sources imply higher negative effects than other sources (i.e., industries), as a consequence of the closer distance between the exhaust pipes and the people in transport-related microenvironments.

In spite of its relevance for public health, the exposure of bikepaths users to air pollution in Bogotá has so far received limited attention and few researches have been conducted. One previous study (Fajardo and Rojas, 2012), drew as a conclusion the need for a more detailed characterization of the environmental conditions of bikers in the city. The main objective of our work is to measure the levels of fine particulate matter $\left(\mathrm{PM}_{2.5}\right)$ and black carbon (BC) to which bike-paths users are exposed in Bogotá. In addition, we identified some of the factors that must be considered when designing bike-dedicated infrastructure to minimize users' exposure.

\section{METHODS}

\section{Study Area and Selection of the Bike-Paths}

This study was conducted in the urban area of Bogotá D.C., Colombia's capital and largest city (8 million inhabitants; DNP, 2015). It is located on the Andes mountain range, at 2600 m.a.s.l. with a temperate climate, no marked seasonal variation $(\mathrm{Cfb}$, according to the Köppen-Geiger classification), and with an average temperature of $13.5^{\circ} \mathrm{C}$ and an average rainfall of 866 $\mathrm{mm} /$ year. The city urban area and its dwellers are classified in six socio-economical strata (with stratum 1 being the lowest and stratum 6 the highest), with people living in strata 2 and 3 accounting for about $80 \%$ of the total population (DAPD, 2007). The economy of Bogotá represents 25\% of the GDP of the country, with prominent sectors being those of services, commerce, and manufacturing (Luna and Behrentz, 2011).

More than 10 million trips occur daily within the city in both motorized and bicycle modes. Public transportation, which includes massive transport (a bus rapid transit system known as Transmilenio), conventional buses and micro-busses, and taxis, accounts for $\sim 60 \%$ of the daily trips (CCB, 2015).

The selected bike-paths are located alongside major streets. We chose bike-paths with distinct configurations (see Table 1 and Figure 1). One type is a bike-path located at the center of the corridor, in the division between lanes in a two-way street. The other type is a bike-path at the right-side of the street. Cycle lanes are segregated in both cases. In addition, we considered the street geometry to represent different diffusion conditions. We chose two paths located along narrow streets (average street width less or equal than $30 \mathrm{~m}$ ) with a consistent canyon configuration along the selected transects, and two paths located on wide streets (average street width $>50 \mathrm{~m}$ ) with variable configuration of flanking buildings. Moreover, we only consider bike-paths located in streets with mixed traffic where both public and private transport modes operate. These types of streets are representative for the bike-paths locations in Bogotá.

Taking into account the average length of bike trips in the city (7 km according to SDM, 2013), we selected a section of a similar distance on each bike-path to run our experiments. Safety conditions for the field team and logistic factors were also considered in the final selection of the bike-paths.

\section{Field Data Collection}

The field campaign was conducted in 2013 between April and May. For each bike-path we conducted two (or more) experiments during work days and two during weekends (always on Sundays). Each experiment consisted of a data collection along the bike-path, with a specially equipped bike for the simultaneous and real-time measurement of $\mathrm{PM}_{2.5}$ and $\mathrm{BC}$ concentrations. Bike users were asked to bike at their average speed.

To measure $\mathrm{PM}_{2.5}$ concentrations we used a portable photometer DustTrak 8533 (TSI Inc., USA) with a flow rate of $1.5 \mathrm{l} / \mathrm{min}$. The DustTrak uses 90-deg light scattering to quantify the mass concentration of particles in an air stream that passes through an impactor assembly (Yanosky et al., 2002). The instrument was factory calibrated, and zero point and flow rate were verified and/or reset according to the manufacturer's instructions prior to each experiment.

Real-time BC concentrations were obtained using a microaethalometer model AE51 (AethLabs Inc., USA). Operating at a flow rate of $100 \mathrm{ml} / \mathrm{min}$, the AE51 performs the analysis by measuring the rate of change in absorption of transmitted light 


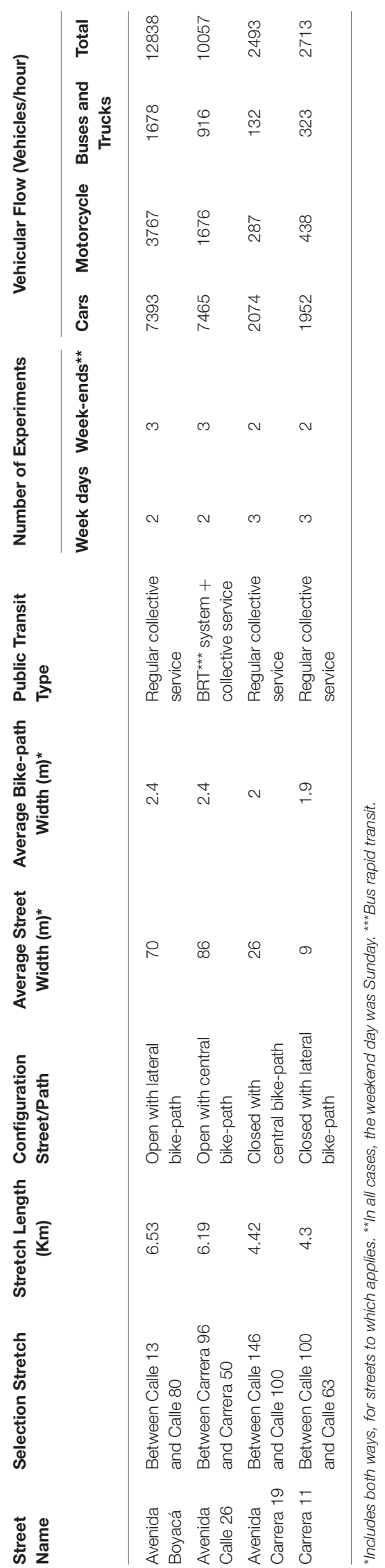

$(880 \mathrm{~nm})$ due to continuous collection of aerosol deposit on a filter media. On each experiment geographical position was register using a GARMIN 60CSX. All the instruments were set to 1 -s time resolution.

Dates and times of each experiment are reported in Table 2, together with background concentrations of $\mathrm{PM}_{2.5}$ and meteorological data obtained from the city's air quality monitoring network for the same dates and times of the experiments.

We selected a time frame between 6:00 and 9:30 a.m. to do the experiments. According to the hourly distribution of the bike trips in the city (SDM, 2012), the peak of the bike trips corresponds to that period (about 60,000 trips/hour). Data regarding vehicular volume at the corridors was obtained from the transport local authorities. This information is reported in Table $\mathbf{1}$ and in all cases corresponds to workdays.

\section{Field Data Processing}

Field data was downloaded using the specific software of each measuring instrument. A total of 33,700 observations were obtained. Each of them consisted of a tuple with a measured level of $\mathrm{PM}_{2.5}$, BC, and the GPS coordinates.

All the observations were submitted to a process of filtering and validation. The filtering consisted in the identification and removal of spurious values, generated by equipment errors. Null and negative values were removed, as well as extreme ones outside of the data trend (e.g., spikes), which were obviously spurious measurements determined by mechanical stresses affecting the data collection devices. The validation process implemented a cross-check of pollutant levels, identifying, and removing all observations for which the $\mathrm{PM}_{2.5}$ was not greater than that of $\mathrm{BC}$. This validation processes removed $11 \%$ of the observations.

We computed descriptive statistics of the measured data to identify its variability range, average standard deviation, distribution, and to determine the percentage of observations above the threshold values (WHO and national regulations).

We analyzed pollution levels with their geographical position, to identify differences in exposure levels along the bike-path and analyze possible impacts from crossings, traffic lights, and bus stops on the air quality.

A different analysis considered an aggregation of data to compute the average values of $\mathrm{PM}_{2.5}$ and $\mathrm{BC}$ during workdays and weekends. For the estimation of the average measures, we used confidence intervals to determine a measure of the error or uncertainty. As it was not possible to assume that the measurement data was normally distributed, we used empirical bootstrap confidence intervals (Efron and Tibshirani, 1993) at a 95\% confidence level.

We then used a boxplot visualization (with standard settings, Q1, Q2, and Q3, whiskers at 1.5 times the interquartile range, outliers not plotted) of the measured concentrations of air pollutants to determine possible differences in their distributions across bike-paths and with respect to the day of the measurement (i.e., workday or weekend).

For each of the bike-paths, we ran a one-way ANOVA to ascertain the existence of a statistical difference between the 


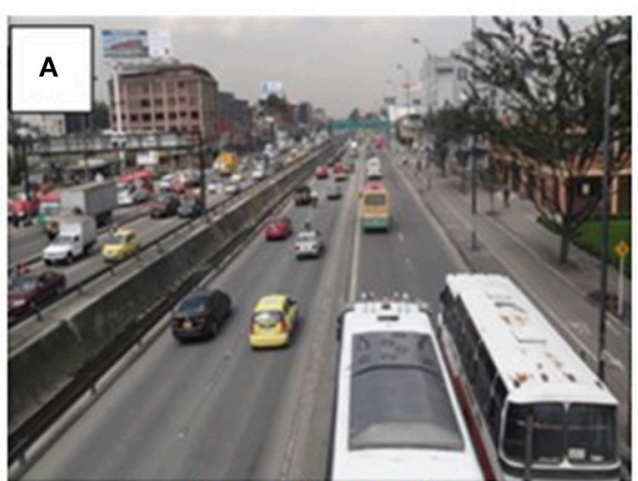

Avenida Boyacá

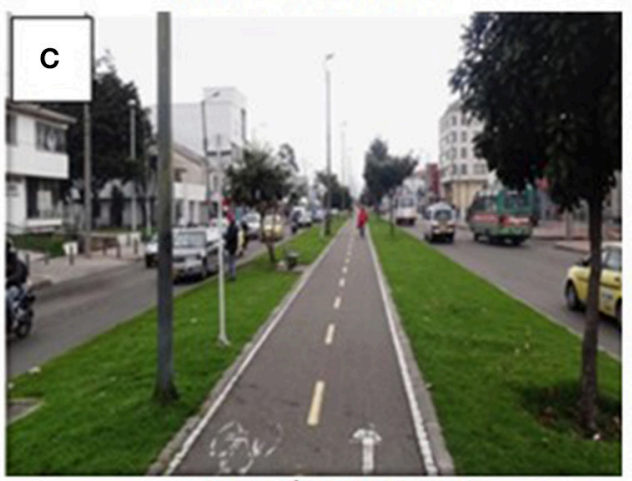

Avenida Carrera 19

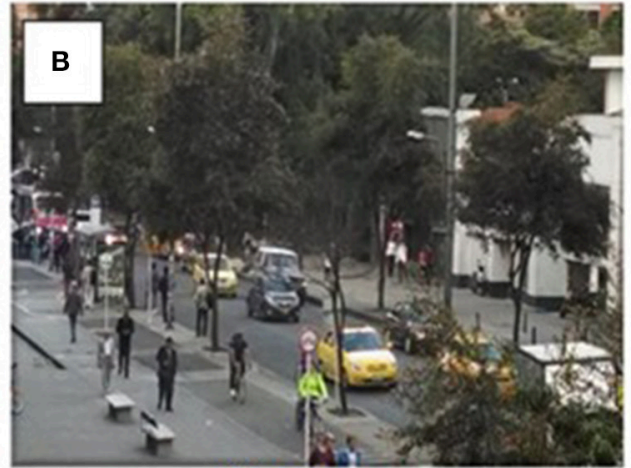

Carrera 11

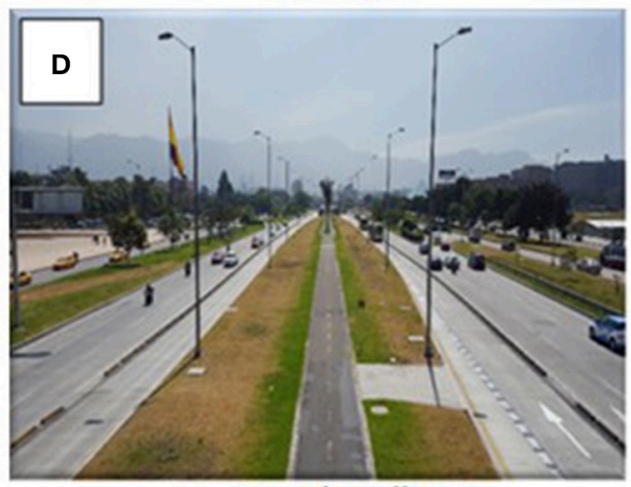

Avenida Calle 26

FIGURE 1 | Configuration of the streets and bike-paths selected for this study. (A) Open street with lateral bike-path; (B) closed street with lateral bike-path; (C) closed street with central bike-path; (D) open street with central bike-path.

TABLE 2 | Summary of the field data, pollutant levels and meteorological conditions.

\begin{tabular}{|c|c|c|c|c|c|c|c|c|c|c|}
\hline \multicolumn{5}{|c|}{ Experiment details } & \multicolumn{3}{|c|}{ Air pollutants concentrations $\left(\mu \mathrm{g} / \mathrm{m}^{3}\right)$} & \multicolumn{3}{|c|}{ Meteorological data } \\
\hline Avenida & Sun & $21 / 04 / 2013$ & 9:12:49 & 9:48:00 & $43.6(61.1)$ & $28.0(35.0)$ & 20.0 & 566.5 & 0.3 & 1.60 \\
\hline \multirow[t]{2}{*}{ Boyacá } & Wed & $24 / 04 / 2013$ & 8:20:01 & 9:04:13 & $102.4(89.8)$ & $22.5(17.2)$ & 39.0 & 565.6 & 0.1 & 1.23 \\
\hline & Thu & $25 / 04 / 2013$ & 8:23:18 & 8:52:00 & $156.2(143.5)$ & $48.8(44.0)$ & 18.0 & 565.5 & 0.0 & 0.87 \\
\hline \multirow[t]{4}{*}{ Calle 26} & Sun & $21 / 04 / 2013$ & 7:50:00 & 8:25:00 & $19.0(19.9)$ & $12.2(13.9)$ & 21.0 & 566.5 & 0.2 & 1.14 \\
\hline & Wed & $24 / 04 / 2013$ & 7:11:28 & 7:45:00 & $160.5(44.7)$ & $26.5(19.2)$ & 42.0 & 565.6 & 0.0 & 1.21 \\
\hline & Thu & $25 / 04 / 2013$ & 7:27:09 & $7: 54: 00$ & $105.8(40.5)$ & $48.8(23.0)$ & 18.0 & 565.5 & 0.0 & 0.87 \\
\hline & Sun & 28/04/2013 & $7: 24: 00$ & $7: 54: 00$ & $83.5(15.1)$ & $22.7(17.6)$ & 40.0 & 564.8 & 0.0 & 1.29 \\
\hline \multirow[t]{2}{*}{ Carrera 19} & Sun & $5 / 05 / 2013$ & 7:18:42 & $7: 45: 27$ & $27.2(39.8)$ & $11.0(14.1)$ & 24.0 & 566.3 & 0.8 & 1.27 \\
\hline & Thu & 9/05/2013 & $7: 37: 08$ & 8:04:08 & 100.5 (228.9) & $22.4(32.1)$ & 37.0 & 566.4 & 0.0 & 1.22 \\
\hline \multirow[t]{5}{*}{ Carrera 11} & Sun & $5 / 05 / 2013$ & $7: 54: 51$ & 8:18:06 & 51.5 (76.3) & 24.1 (28.3) & 18.0 & 566.3 & 0.5 & 1.25 \\
\hline & Thu & $9 / 05 / 2013$ & $8: 15: 29$ & $8: 40: 11$ & $136.1(156.5)$ & $44.3(65.4)$ & 26.0 & 566.4 & 0.0 & 1.18 \\
\hline & Sun & $12 / 05 / 2013$ & $7: 37: 59$ & 7:56:04 & 79.8 (173.6) & $12.6(12.1)$ & 39.0 & 565.0 & 0.1 & 1.27 \\
\hline & Wed & $15 / 05 / 2013$ & $7: 46: 32$ & 8:07:01 & $113.1(192.1)$ & $19.6(21.4)$ & 40.0 & 565.0 & 0.1 & 1.46 \\
\hline & Thu & $23 / 05 / 2013$ & $7: 32: 25$ & $7: 55: 09$ & $135.3(167.9)$ & $16.3(14.1)$ & 45.0 & 565.5 & 0.0 & 0.91 \\
\hline
\end{tabular}


averages of the concentrations of $\mathrm{PM}_{2.5}$ and $\mathrm{BC}$ measured during workdays and weekends. This analysis led us to conduct a more detailed graphical characterization of the distributions of the air contaminants, of their correlation, and of the differences between the amounts measured during workdays and weekends.

\section{RESULTS AND DISCUSSION}

Table 3 shows the descriptive statistics for the total number of valid observations of $\mathrm{PM}_{2.5}$ and $\mathrm{BC}$. For $\mathrm{PM}_{2.5}$, more than $75 \%$ of the measurements are above the 24 -h threshold value of $25 \mu \mathrm{g} / \mathrm{m}^{3}$ set by WHO, with extreme values beyond $1000 \mu \mathrm{g} / \mathrm{m}^{3}$. The measurements of $\mathrm{BC}$ concentrations raise similar worries (i.e., $33 \%$ of the measurements are higher than $25 \mu \mathrm{g} / \mathrm{m}^{3}$ ).

Figure 2 shows the histograms for $\mathrm{PM}_{2.5}$ and $\mathrm{BC}$ considering all the samples (for both measurements the rightmost part of the distribution was cut for the sake of visualization). Both distributions of values are exhibiting a long tail, as also indicated by the coefficient of variation $>1$ (see Table 3). Moreover, the distribution of $\mathrm{PM}_{2.5}$ shows multimodality, which can be attributed to the presence of multiple emitting sources along the bike-paths.

Both pollutants show highly dynamical patterns in its concentrations, with many swift peaks. Figure 3 shows a georeferenced display of $\mathrm{PM}_{2.5}$ concentrations along the four bike-paths (for one specific experiment). Different levels of each pollutant are represented by using a color scale, were the nuances of red are assigned to the highest concentration levels and those of blue to the lowest ones. Bikers are exposed to highly variable pollution levels during their bike ride.

For those particular experiments we reported in Figure 3, the highest concentrations were recorded in the proximity to the main road crossing (e.g., along bike-path c), but also close to traffic lights and public transportation bus stops along the street (e.g., along bike-path a). The results of this analysis, as well as the proximity of the bike-paths to the street, indicate that the concentrations of air pollutants to which bikers are exposed are highly influenced by vehicular traffic emissions.

Figure 4 presents the average and the $95 \%$ confidence interval for $\mathrm{PM}_{2.5}$ and $\mathrm{BC}$ concentrations, classed by workdays and weekends. These charts confirm cyclists are consistently exposed to high concentrations of both pollutants, irrespective of the type of day. For $\mathrm{PM}_{2.5}$, the average concentration is within 80 and 136 $\mu \mathrm{g} / \mathrm{m}^{3}$ for workdays. These levels are three to five times higher than those suggested by the WHO (if we take the $24 \mathrm{~h}-25 \mu \mathrm{g} / \mathrm{m}^{3}$ as a reference value). During weekends, the concentrations of this pollutant ranged between 30 and $72 \mu \mathrm{g} / \mathrm{m}^{3}$.

The average concentrations of $\mathrm{BC}$ were between 16 and 38 $\mu \mathrm{g} / \mathrm{m}^{3}$ during workdays and in the range of $10-32 \mu \mathrm{g} / \mathrm{m}^{3}$ during weekends. Such air pollution levels are relevant from a

TABLE 3 | Descriptive statistics.

\begin{tabular}{|c|c|c|c|c|c|c|c|c|c|c|}
\hline & Min & Median & Mean & Max & $\begin{array}{l}\text { Standard } \\
\text { Deviation }\end{array}$ & $\begin{array}{c}\text { Coeff. } \\
\text { Variation }\end{array}$ & $\begin{array}{c}\% \\
>25 \mu \mathrm{g} / \mathrm{m}^{3}\end{array}$ & $\begin{array}{c}\% \\
>50 \mu \mathrm{g} / \mathrm{m}^{3}\end{array}$ & $\begin{array}{c}\% \\
>100 \mu \mathrm{g} / \mathrm{m}^{3}\end{array}$ & $\begin{array}{c}\% \\
>200 \mu \mathrm{g} / \mathrm{m}^{3}\end{array}$ \\
\hline $\mathrm{PM}_{2.5}\left(\mu \mathrm{g} / \mathrm{m}^{3}\right)$ & 1.0 & 68.0 & 92.6 & 3604.0 & 115.2 & 1.2 & 77 & 60 & 31 & 8 \\
\hline $\mathrm{BC}\left(\mu \mathrm{g} / \mathrm{m}^{3}\right)$ & 1.1 & 15.3 & 25.6 & 3157.0 & 39.2 & 1.6 & 34 & 13 & 3 & 1 \\
\hline
\end{tabular}
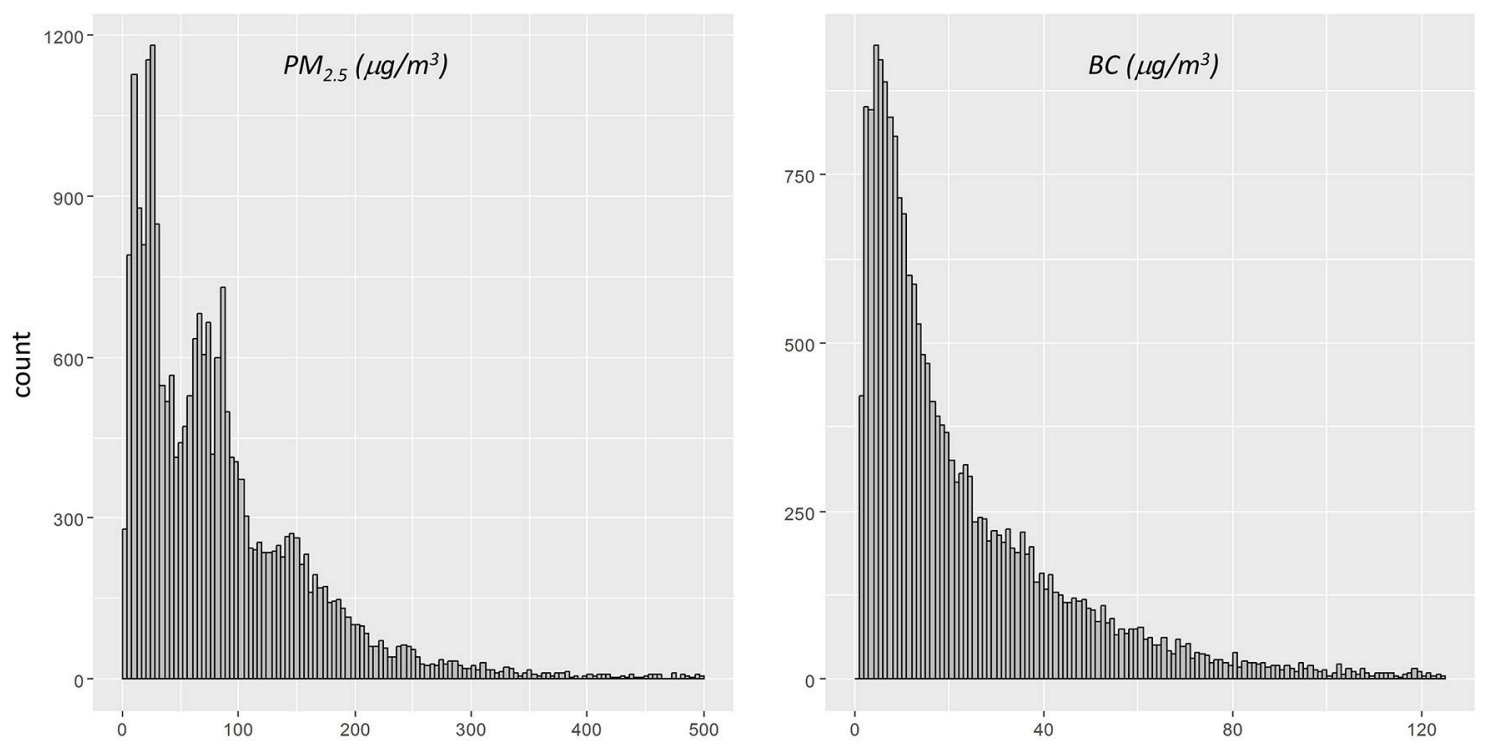

FIGURE 2 | Histograms of $\mathrm{PM}_{2.5}$ and $\mathrm{BC}$ concentrations measured along the bike-paths. 


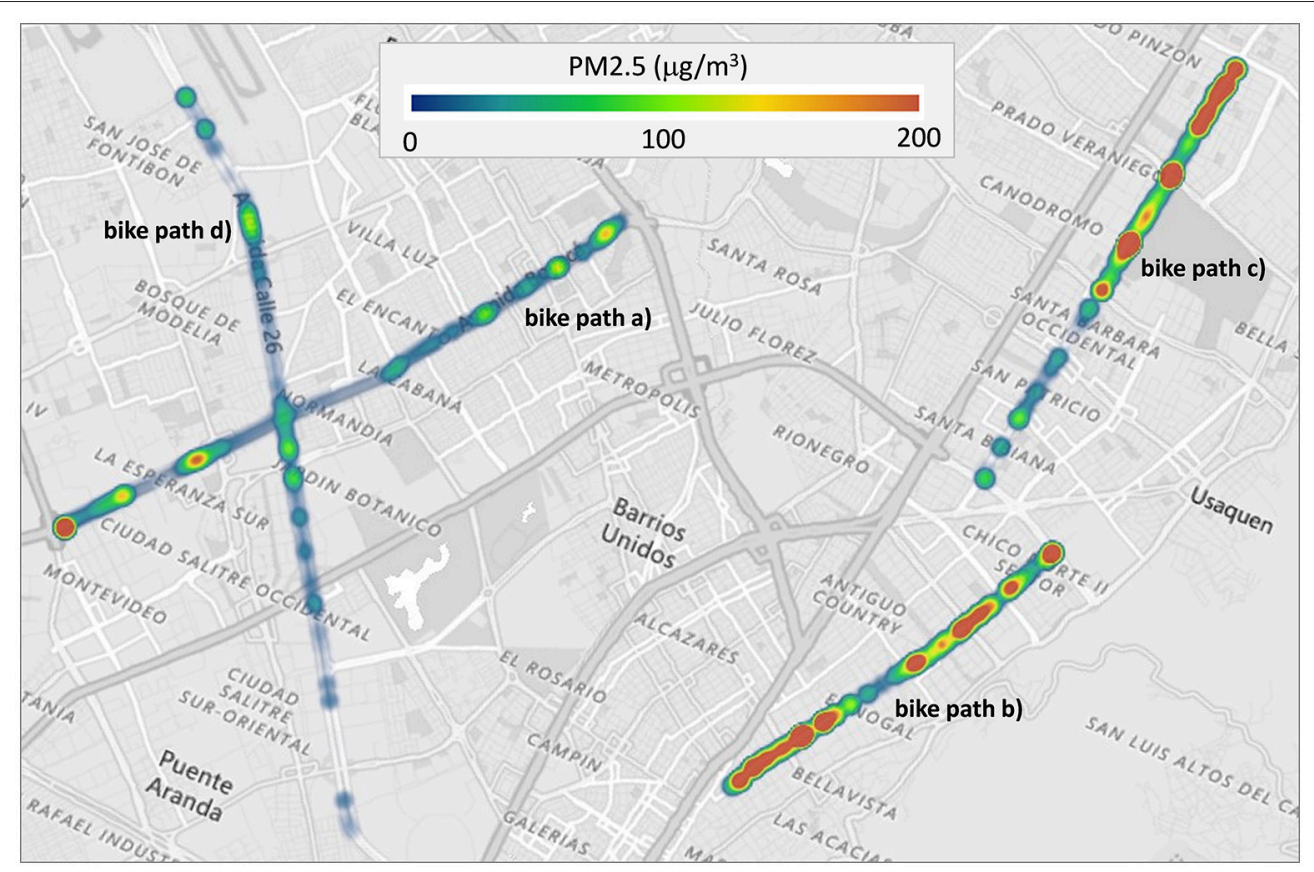

FIGURE 3 | Concentrations of $\mathrm{PM}_{2.5}$ measured during data collection experiments along the four selected bike-paths.

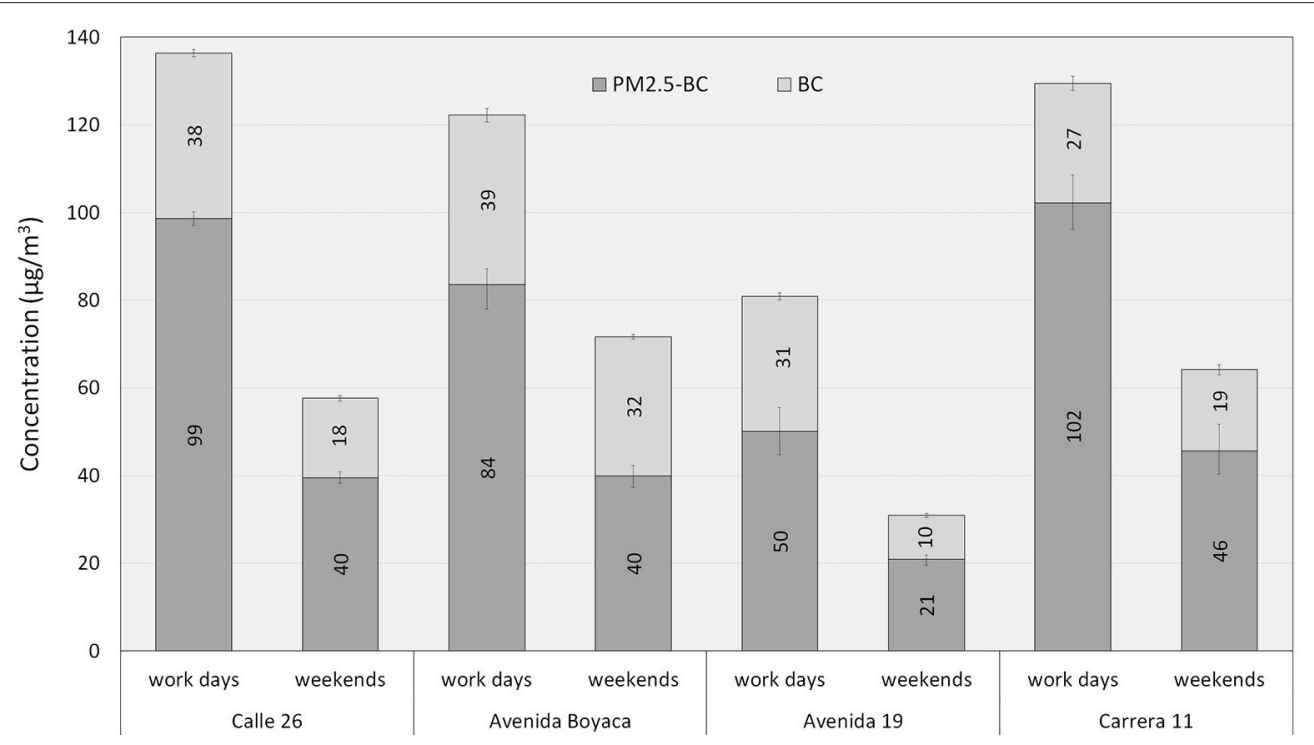

FIGURE 4 | Average concentrations and 95\% confidence intervals for $\mathrm{PM}_{2.5}\left(\mu \mathrm{g} / \mathrm{m}^{3}\right)$ and $\mathrm{BC}\left(\mu \mathrm{g} / \mathrm{m}^{3}\right)($ all the bike-paths, classed by work days and weekends).

public health point of view, considering the positive association of the exposure to particle related pollutants with respiratory and cardiovascular problems (Calderón-Garcidueñas et al., 2003; Kim, 2004; WHO, 2005; Holguin et al., 2007).

We compared the results of this study with the measured concentrations to which bike users are exposed to in other cities of the world. The $\mathrm{PM}_{2.5}$ levels found in Bogotá are up to one order of magnitude higher than those measured in the proximity of streets along bike-paths in cities such as Minneapolis and Berkeley in the United States (Jarjour et al., 2013; Hankey and Marshall, 2015). They are up to three times higher than the concentrations recorded in European cities (Adams et al., 2001; Zuurbier et al., 2010); in the same range of those measured in Beijing, China (Huang et al., 2012), and lesser than those reported 
for Indian cities, such as New Delhi (Goel et al., 2015). Similarly, $\mathrm{BC}$ concentrations measured in this study were up to two orders of magnitude higher than those observed in North American cities (Jarjour et al., 2013; MacNaughton et al., 2014; Hankey and Marshall, 2015). Table 4 presents a summary of the studies cited above.

In a previous study conducted in Bogotá, Fajardo and Rojas (2012) determined the concentration levels of $\mathrm{PM}_{10}$ in two sites along a bike-path located on a major city avenue. They reported $\mathrm{PM}_{10}$ average concentrations between 77 and $108 \mu \mathrm{g} / \mathrm{m}^{3}$, and concluded that people who regularly use bikes in Bogotá can inhale doses of particulate matter between 45 and $65 \%$ higher than the doses inhaled by people who do not use bikes.

Accounting for the day of the week when each experiment was conducted, and the traffic volume, we can conclude that the dynamics of vehicular traffic during the week has a significant impact on the $\mathrm{PM}_{2.5}$ and $\mathrm{BC}$ concentrations in the proximity of streets. A statistically significant difference exists in pollutant concentrations measured during workdays and weekends at each of the four streets considered (see confidence intervals in Figure 4).

For $\mathrm{PM}_{2.5}$, in streets such as Carrera 19, the average concentration during workdays is about three times the one measured during weekends, where the vehicular flow is lesser (according to local mobility authorities, Sundays' total public transit traffic is $\sim 50 \%$ lesser than in workdays). For BC, streets that bear a higher share of heavy traffic during workdays, such as Calle 26 and Avenida Boyacá, were those with the highest $\mathrm{BC}$ concentrations. We compared means of workdays and weekends for each street by a one-way ANOVA test, and in each case we found that the null hypothesis (i.e., mean concentrations are the same) can be rejected with a very small $p$ value $\left(<5 \times 10^{-8}\right)$. These conclusion has been remarked by other authors (Berghmans et al., 2008; Int Panis et al., 2010; Fajardo and Rojas, 2012). Figure 5 provides a graphical appreciation of the differences in the distribution of the measured pollutants during workdays and weekends.

Figure 6 shows scatter plots for the pairwise concentrations of $\mathrm{BC}$ and $\mathrm{PM}_{2.5}-\mathrm{BC}$ measured during workdays and weekends for the bike-paths along Carrera 19 and Calle 26. There is not graphical evidence of significant correlation between the two measurements. This could be explained by the simultaneous coexistence of different emitting sources. Similar results have been obtained for the other two bike-paths (data not shown).

The charts at the top and at the right of the scatter plots in Figure 6 are providing the distribution of the measured

TABLE 4 | International studies assessing the exposure levels of bike-path users.

\begin{tabular}{|c|c|c|c|c|c|c|}
\hline Authors & Location & $\begin{array}{l}\text { Particle size } \\
\text { measured }\end{array}$ & Equipment & Mean & Minimum & Maximum \\
\hline Adams et al., 2001 & London, UK & $\mathrm{PM}_{2.5}$ & $\begin{array}{l}\text { Gravimetric High Flow } \\
\text { Personal Sampler } \\
\text { (HFPS) }\end{array}$ & $\begin{array}{l}34.5 \mu \mathrm{g} / \mathrm{m}^{3} \text { (Summer) } \\
23.5 \mu \mathrm{g} / \mathrm{m}^{3} \text { (Winter) }\end{array}$ & $\begin{array}{l}13.3 \mu \mathrm{g} / \mathrm{m}^{3} \text { (Summer) } \\
6.8 \mu \mathrm{g} / \mathrm{m}^{3} \text { (Winter) }\end{array}$ & $\begin{array}{l}68.7 \mu \mathrm{g} / \mathrm{m}^{3} \text { (Summer) } \\
76.2 \mu \mathrm{g} / \mathrm{m}^{3} \text { (Winter) }\end{array}$ \\
\hline Zuurbier et al., 2010 & $\begin{array}{l}\text { Amhem, } \\
\text { Netherlands }\end{array}$ & $\mathrm{PM}_{2.5}$ & $\begin{array}{l}\text { Real time active } \\
\text { sampling DataRAMs } \\
\text { model } 1200 \text { with a } \\
\text { PM }_{2.5} \text { cyclone model } \\
\text { GK } 2.05\end{array}$ & $\begin{array}{l}71.7 \mu \mathrm{g} / \mathrm{m}^{3} \text { (Low-traffic } \\
\text { bicycle) } 72.3 \mu \mathrm{g} / \mathrm{m}^{3} \\
\text { (High-traffic bicycle) }\end{array}$ & - & - \\
\hline Huang et al., 2012 & Beijing, China & $\mathrm{PM}_{2.5}$ & $\begin{array}{l}\text { Portable Aerosol } \\
\text { Spectrometer Model } \\
\text { LD-6S }\end{array}$ & $49.1 \mu \mathrm{g} / \mathrm{m}^{3}$ & $18.96 \mu \mathrm{g} / \mathrm{m}^{3}$ & $112.47 \mu \mathrm{g} / \mathrm{m}^{3}$ \\
\hline Jarjour et al., 2013 & Berkeley, USA & $\mathrm{PM}_{2.5}$ & DustTrak 8520 & $\begin{array}{l}4.88 \mu \mathrm{g} / \mathrm{m}^{3} \text { (Low Traffic) } \\
5.12 \mu \mathrm{g} / \mathrm{m}^{3} \text { (High Traffic) }\end{array}$ & $\begin{array}{l}2.25 \mu \mathrm{g} / \mathrm{m}^{3} \text { (Low Traffic) } \\
2.25 \mu \mathrm{g} / \mathrm{m}^{3} \text { (High Traffic) }\end{array}$ & $\begin{array}{l}20.96 \mu \mathrm{g} / \mathrm{m}^{3} \text { (Low Traffic) } \\
27.40 \mu \mathrm{g} / \mathrm{m}^{3} \text { (High Traffic) }\end{array}$ \\
\hline \multirow[t]{2}{*}{$\begin{array}{l}\text { Hankey and Marshall, } \\
2015\end{array}$} & $\begin{array}{l}\text { Minneapolis, } \\
\text { USA }\end{array}$ & $\mathrm{PM}_{2.5}$ & DustTrak 8530 & $\begin{array}{l}10.9 \mu \mathrm{g} / \mathrm{m}^{3} \text { (Morning) } 9.4 \\
\mu \mathrm{g} / \mathrm{m}^{3} \text { (Afternoon) }\end{array}$ & - & - \\
\hline & & $\mathrm{BC}$ & microAeth AE51 & $\begin{array}{l}2.7 \mu \mathrm{g} / \mathrm{m}^{3} \text { (Morning) } 0.8 \\
\mu \mathrm{g} / \mathrm{m}^{3} \text { (Afternoon) }\end{array}$ & - & - \\
\hline Goel et al., 2015 & Delhi, India & $\mathrm{PM}_{2.5}$ & DustTrak 8533 & $\begin{array}{l}347 \mu \mathrm{g} / \mathrm{m}^{3} \text { (January) } 285 \\
\mu \mathrm{g} / \mathrm{m}^{3} \text { (February) }\end{array}$ & - & - \\
\hline \multirow[t]{2}{*}{ This work } & $\begin{array}{l}\text { Bogotá, } \\
\text { Colombia }\end{array}$ & $\mathrm{PM}_{2.5}$ & DustTrak 8533 & $\begin{array}{l}\text { 80-136 } \mu \mathrm{g} / \mathrm{m}^{3} \\
\text { (Weekdays) 30-72 } \mu \mathrm{g} / \mathrm{m}^{3} \\
\text { (Weekdays) }\end{array}$ & & \\
\hline & & $\mathrm{BC}$ & microAeth AE51 & $\begin{array}{l}16-38 \mu \mathrm{g} / \mathrm{m}^{3} \text { (Weekdays) } \\
10-32 \mu \mathrm{g} / \mathrm{m}^{3} \text { (Weekdays) }\end{array}$ & & \\
\hline
\end{tabular}



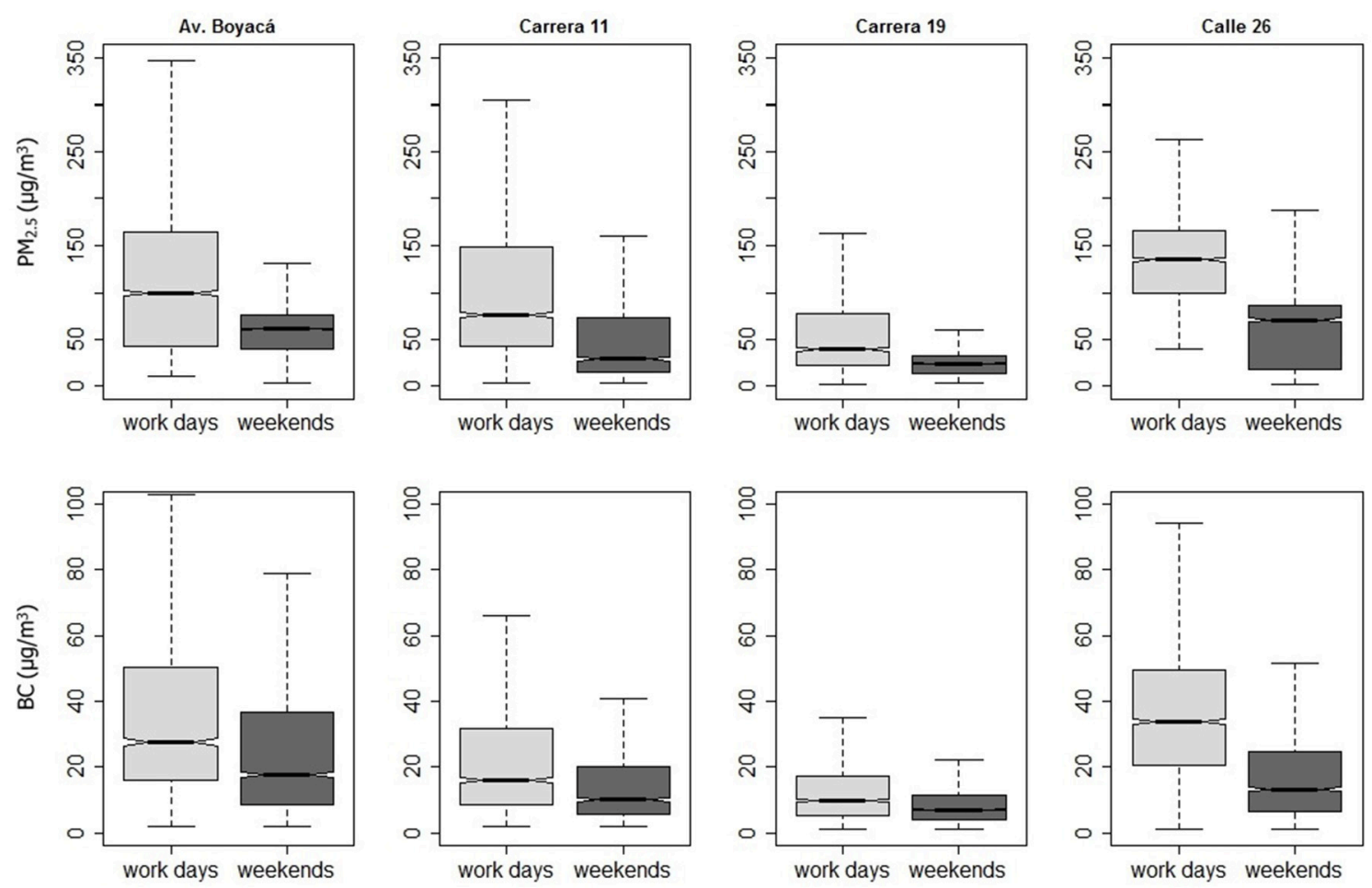

FIGURE 5 | Comparison between the distribution of concentrations of $\mathrm{PM}_{\mathbf{2 . 5}}$ and $\mathrm{BC}$ measured in workdays and weekends (all the bike-paths). The borders of the boxes indicate the first quartile (Q1), second (median), and third quartile (Q3) of the distribution, and the whiskers are located at 1.5 times the Q3-Q1 distance from the closest quartile.
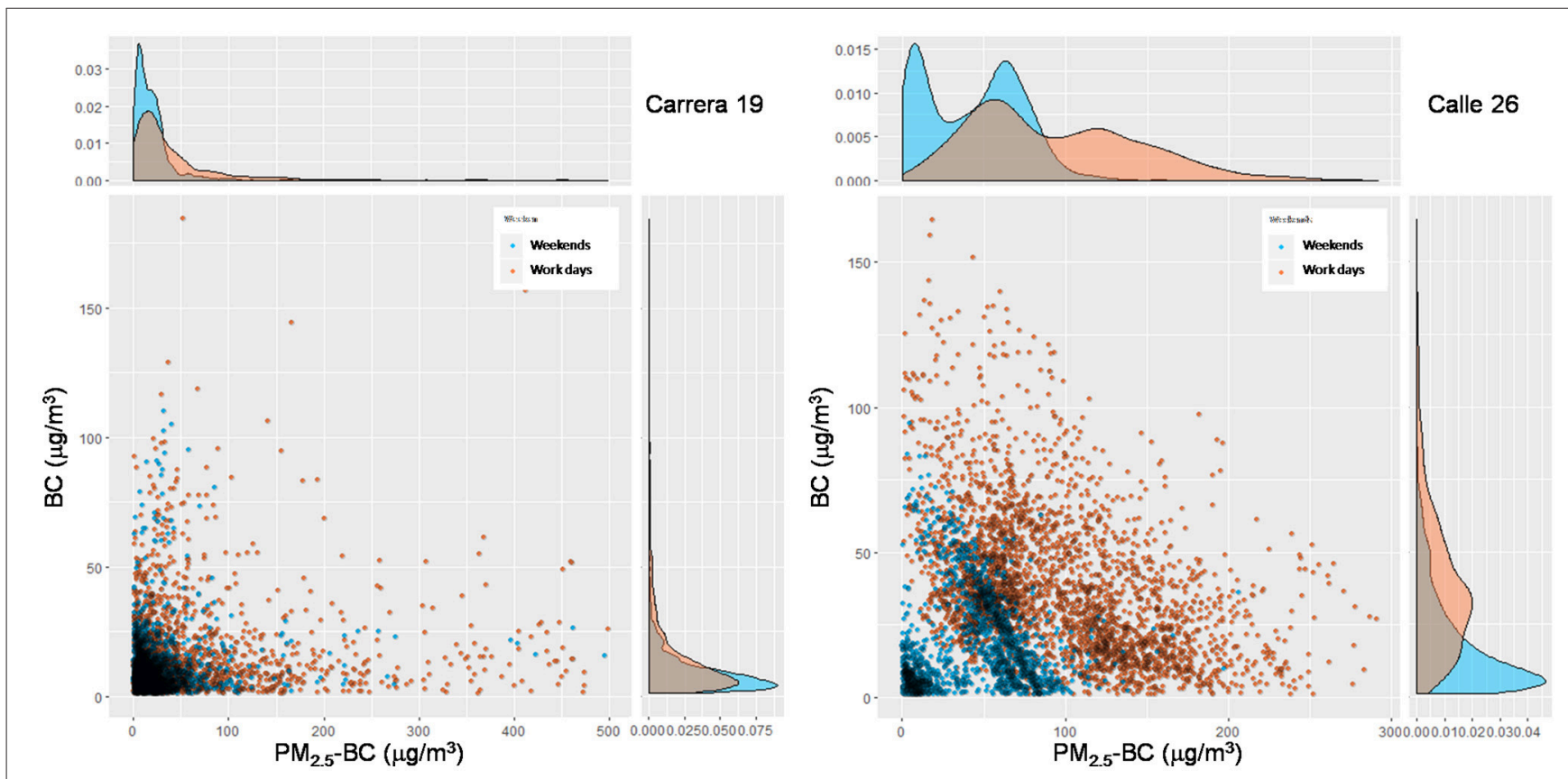

FIGURE 6 | Scatter plots and distributions of $\mathrm{PM}_{2.5}$ and $\mathrm{BC}$ concentrations measured along two bike-paths, during work days and weekend. 
concentrations. The distribution for $\mathrm{PM}_{2.5}-\mathrm{BC}$ for Calle 26 shows a very pronounced bimodality, both during workdays and weekend days. This important avenue of Bogotá is very wide, with large stretches of fluid vehicular traffic. However, it has several intersections with mayor confluent streets, where traffic jams are constant. Such diverse conditions may be a cause of the prominent bimodality.

It is also important to remark the impact that the usage of paths located on narrow, closed geometry streets may have on bikers' level of exposure to air pollution. Even though the total vehicular traffic along the narrowest street considered in this study (Carrera 11) is about four times lesser than the one in the largest and open geometry one (Calle 26), the concentrations of $\mathrm{PM}_{2.5}$ and $\mathrm{BC}$ (as measured during workdays) were practically equivalent. Even if several other elements are still to be analyzed at a finer level, these results suggest that the geometry of the streets can significantly affect air pollutant dispersion, increasing levels of exposure for bike-path users.

While promoting the bicycle as an alternative transport mode in Bogotá, it would be significant to stress the importance of reducing air pollution exposure levels of cyclists. It appears advisable to consider using secondary, low traffic level streets, for new bike dedicated infrastructure, as well as physical barriers in heavy-traffic roads were existing bike-paths are located. Also, it is urgent to actively promote emission control systems on mobile sources such as particulate filters, as well as to encourage the massive use of face filter masks among bike users. This fact clearly indicates the need of more accurate studies on the interrelations between mobility strategies and their effects on public health.

\section{UNCERTAINTY AND RESULTS REPRESENTATIVENESS}

It is well-documented that DustTrak and Aethalometer monitors readings may diverge from the standard PM determination methods (Ramachandran et al., 2000; Yanosky et al., 2002; Wallace et al., 2011). The readings of photometers such as DustTrak monitors may overestimate the concentration of airborne particulate matter compared to gravimetric techniques (Gorner et al., 1995; Ramachandran et al., 2000; Tasić et al., 2012). We previously reported results from specific experiments carried out to compare and validate the two methods for mass concentrations measurement in Bogotá (Franco et al., 2009, 2013). Even though those local comparisons were only conducted to assess $\mathrm{PM}_{10}$ concentrations, we believe that under our

\section{REFERENCES}

Adams, H. S., Nieuwenhuijsen, M. J., Colvile, R. N., McMullen, M. A., and Khandelwal, P. (2001). Fine particle $\left(\mathrm{PM}_{2.5}\right)$ personal exposure levels in transport microenvironments, London, U. K. Sci. Total Environ. 279, 29-44. doi: 10.1016/S0048-9697(01)00723-9

Baumann, C., Bojacá, M., Rambeau, M., and Wanner, Z. (2013). Biciciudades 2013: Regional Study on the Use of the Bicycle As a Mode of Transportation in Latin study conditions, DustTrak monitors provided representative information on the range of PM concentration. In addition, other authors (Wallace et al., 2011) have shown that continuous monitors such as DustTrak and Aethalometer can provide reliable information for environmental studies.

The authors are aware of the representativeness limits of the results in terms of the number of experiments and bikepaths addressed. However, they believe this pilot study can provide useful data for an improved understanding of air quality conditions for bikers in Bogotá and in other Latin American cities.

\section{CONCLUSIONS}

For the very first time for Bogotá, we quantified in this study $\mathrm{PM}_{2.5}$ and $\mathrm{BC}$ concentrations at bike-paths located alongside major streets. Bicycle is a sustainable mode of transport and it has important health benefits for the population. However, the pollution levels indicate the existence of low air quality conditions and show that cyclists are exposed to concentrations that largely exceed the threshold values established as potentially dangerous for human health. We consider these results provide useful insights to increase the appreciation of this problem in Latin American cities and to contribute with technical elements that lead to the inclusion of air quality variables when designing and planning sustainable urban mobility infrastructures.

\section{AUTHOR CONTRIBUTIONS}

JF, JS, and IM were involved in field work design. JF and JS were in charge of the data collecting process. JF and IM were in charge of the data processing process. JS contributed in structuring the paper, and JF and IM wrote the final version. All authors supported the experiments, critically commented, and revised the manuscript.

\section{ACKNOWLEDGMENTS}

The authors acknowledge the financial support provided by Universidad EAN for the data collection campaign and the partial funding of the Colombian Department of Science, Technology and Innovation (COLCIENCIAS) under the figure of a junior-scientist agreement. In particular, we thank the contribution of professor Daniel Gomez as an in-house supervisor for the agreement between Universidad EAN and COLCIENCIAS. SPA\%20REPORT\%209-10-13.pdf

Berghmans, P., Bleux, N., Int Panis, L., Mishra, V. K., Torfs, R., and Van Poppel, M. (2008). Exposure assessment of a cyclist to PM10 and ultrafine particles. Sci. Total Environ. 407, 1286-1298. doi: 10.1016/j.scitotenv.2008. 10.041

Calderón-Garcidueñas, L., Mora-Tiscareño, A., Fordham, L. A., Chung, C. J., Rodriguez-Alcaraz, A., Paredes, D., et al. (2003). Respiratory damage 
in children exposed to urban pollution. Pediatr. Pulmonol. 36, 148-161. doi: $10.1002 /$ ppul.10338

Calderón-Garcidueñas, L., Mora-Tiscareño, A., Fordham, L. A., Chung, C. J., Valencia-Salazar, G., Flores-Gómez, S., et al. (2006). Lung radiology and pulmonary function of children chronically exposed to air pollution. Environ. Health Perspect. 114, 1432-1437. doi: 10.1289/ ehp. 8377

Cámara de comercio de Bogotá (CCB) (2015). Observatorio de Movilidad 2014. Available online at: http://bibliotecadigital.ccb.org.co/handle/11520/13882

Departamento Administrativo de Planeación Distrital (DAPD) (2007). La estratificación en Bogotá, D.C. y Estudios Relacionados 1983-2004. Bogota's Mayor Office, Bogotá, DC.

Departamento Nacional de Planeación (DNP) (2015). Información Departamental, Bogotá, D.C. Población 2015, Censo 2015 - DANE. Available online at: https:// colaboracion.dnp.gov.co/CDT/Inversiones\%20y\%20finanzas\%20pblicas/ Bogot\%C3\%A1\%2015.pdf

Efron, B., and Tibshirani, R. J. (1993). An Introduction to the Bootstrap, Monographs on Statistics and Applied Probability, Vol. 57. New York, NY; London: Chapman and Hall/CRC.

Fajardo, O. A., and Rojas, N. Y. (2012). Particulate matter exposure of bicycle path users in a high-altitude city. Atmos. Environ. 46, 675-679. doi: 10.1016/ j.atmosenv.2011.09.047

Franco, J. F., Yesid Rojas, N., Sarmiento, O. L., Hernández, L. J., Zapata, E., Maldonado, A., et al. (2009). Particulate matter concentrations at public schools located near major urban roads in Bogota, Colombia: pilot study. Rev. Fac. Ing. Univ. Antioquia 49, 101-111. Available online at: http://www.redalyc.org/ articulo.oa?id $=43019324010$

Franco, J. F., Rojas, N. Y., Sarmiento, O. L., and Behrentz, E. (2013). Urban air pollution in school-related microenvironments in Bogota, Colombia. Ingeniería e Investigación 33, 42-48. Available online at: http://www.revistas. unal.edu.co/index.php/ingeinv/article/view/39516/41402

Franco R, J. F. (2012). Contaminación atmosférica en centros urbanos. Desafío para lograr su sostenibilidad: caso de estudio Bogotá. Revista EAN 72, 193-205. Available online at: http://www.scielo.org.co/scielo.php?script=sci_ arttext\&pid=S0120-81602012000100013\&lng=en\&nrm=iso

Fritz, G. J., and Herbarth, O. (2001). Pulmonary function and urban pollution in preschool children. Int. J. Hyg. Environ. Health 203, 235-244. doi: 10.1078/ S1438-4639(04)70034-6

Goel, R., Gani, S., Guttikunda, S. K., Wilson, D., and Tiwari, G. (2015). On-road $\mathrm{PM}_{2.5}$ pollution exposure in multiple transport microenvironments in Delhi. Atmos. Environ. 123, 129-138. doi: 10.1016/j.atmosenv.2015.10.037

Gorner, P., Bemer, D., and Fabries, J. F. (1995). Photometer measurement of polydisperse aerosol. J. Aerosol. Sci. 26, 1281-1302. doi: 10.1016/00218502(95)00049-6

Hankey, S., and Marshall, J. D. (2015). On-bicycle exposure to particulate air pollution: particle number, black carbon, $\mathrm{PM}_{2.5}$, and particle size. Atmos. Environ. 122, 65-73. doi: 10.1016/j.atmosenv.2015.09.025

Holguin, F., Flores, S., Ross, Z., Cortez, M., Molina, M., Molina, L., et al. (2007). Traffic-related exposures, airway function, inflammation, and respiratory symptoms in children. Am. J. Respir. Crit. Care Med. 176, 1236-1242. doi: $10.1164 / \mathrm{rccm} .200611-1616 \mathrm{OC}$

Huang, J., Deng, F., Wu, S., and Guo, X. (2012). Comparisons of personal exposure to $\mathrm{PM}_{2.5}$ and $\mathrm{CO}$ by different commuting modes in Beijing, China. Sci. Total Environ. 425, 52-59. doi: 10.1016/j.scitotenv.2012.03.007

Int Panis, L., De Geus, B., Vandenbulcke, G., Willems, H., Degraeuwe, B., Bleux, N., et al. (2010). Exposure to particulate matter in traffic: a comparison of cyclist and car passengers. Atmos. Environ. 44, 2263-2270. doi: 10.1016/j.atmosenv. 2010.04.028

Jarjour, S., Jerrett, M., Westerdahl, D., de Nazelle, A., Hanning, C., Daly, L., et al. (2013). Cyclist route choice, traffic-related air pollution, and lung function: a scripted exposure study. Environ. Health 12:14. doi: 10.1186/1476-069X$12-14$

Kim, J. J. (2004). Ambient air pollution: health hazards to children. Pediatrics 114, 1699-1707. doi: 10.1542/peds.2004-2166

Kim, J. J., Smorodinsky, S., Lipsett, M., Singer, B. C., Hodgson, A. T., and Ostro, B. (2004). Traffic-related air pollution near busy roads: the East Bay children's respiratory health study. Am. J. Respir. Crit. Care Med. 170, 520-526. doi: 10.1164/rccm.200403-281OC
Luna, D., and Behrentz, E. (2011). Estado de cuentas y nueve propuestas para el buen gobierno de Bogotá, 1st Edn. Bogotá, DC: Comunicaciones y Marketing CESA.

MacNaughton, P., Melly, S., Vallarino, J., Adamkiewicz, G., and Spengler, J. D. (2014). Impact of bicycle route type on exposure to traffic-related air pollution. Sci. Total Environ. 490, 37-43. doi: 10.1016/j.scitotenv.2014.04.111

$\mathrm{Ni}$, L., Chuang, C.-C., and Zuo, L. (2015). Fine particulate matter in acute exacerbation of COPD. Front. Physiol. 6:294. doi: 10.3389/fphys.2015.00294

Peters, J. M., Avol, E., Gauderman, W. J., Linn, W. S., Navidi, W., London, S. J., et al. (1999). A study of twelve Southern California communities with differing levels and types of air pollution: II. Effects on pulmonary function. Am. J. Respir. Crit. Care Med. 159, 768-775. doi: 10.1164/ajrccm.159.3.9804144

Ramachandran, G., Adgate, J. L., Hill, N., Sexton, K., Pratt, G. C., and Bock, D. (2000). Comparison of short-term variations (15-minute averages) in outdoor and indoor $\mathrm{PM}_{2.5}$ concentrations. J. Air Waste Manage. Assoc. 50, 1157-1166. doi: $10.1080 / 10473289.2000 .10464160$

Ríos, R. A., Taddia, A. P., Pardo, C. F., and Lleras, N. (2015). Ciclo-inclusión en América Latina y el Caribe: Guía para impulsar el uso de la Bicicleta. Banco Interamericano de Desarrollo - BID. Available online at: https://publications. iadb.org/handle/11319/6808?locale-attribute=es

Secretaría Distrital de Ambiente de Bogotá (SDA) (2011). Plan Decenal de Descontaminación del Aire de Bogotá. Available online at: http://www. secretariadeambiente.gov.co/sda/libreria/pdf/descargas/LibroPDAAB_final. pdf

Secretaria Distrital de Movilidad (SDM) (2012). Informe de Indicadores Encuesta de Movilidad 2011. Bogotá: Alcaldía Mayor de Bogotá.

Secretaria Distrital deMovilidad (SDM) (2013). Movilidad en Cifras 2012. Bogotá: Alcaldía Mayor de Bogotá.

Secretaría Distrital de Ambiente de Bogotá (SDA) (2014). Informe Anual de la Red de Monitoreo de Calidad del Aire de Bogotá 2013. Bogotá: Alcaldía Mayor de Bogotá, DC.

Tasić, V., Jovašević-Stojanović, M., Vardoulakis, S., Milošević, N., Kovačević, R., and Petrović, J. (2012). Comparative assessment of a real-time particle monitor against the reference gravimetric method for PM10 and $\mathrm{PM}_{2.5}$ in indoor air. Atmos. Environ. 54, 358-364. doi: 10.1016/j.atmosenv.2012.02.030

van Berlo, D., Hullmann, M., and Schins, R. P. F. (2012). "Toxicology of ambient particulate matter," in Molecular, Clinical and Environmental Toxicology, Vol. 3: Environmental Toxicology, ed A. Luch (Basel: Springer), 165-217.

Wallace, L. A., Wheeler, A. J., Kearney, J., van Ryswyk, K., You, H., Kulka, R. H., et al. (2011). Validation of continuous particle monitors for personal, indoor, and outdoor exposures. J. Expo. Sci. Environ. Epidemiol. 21, 49-64. doi: $10.1038 /$ jes.2010.15

World Health Organization (WHO) (2005). Air Quality Guidelines Global Update. Available online at: http://whqlibdoc.who.int/hq/2006/WHO_SDE_ PHE_OEH_06.02_eng.pdf

World Health Organization (WHO) (2016). WHO's Urban Ambient Air Pollution Database - Update 2016. Available online at: http://www.who.int/phe/health_ topics/outdoorair/databases/cities/en/

World Meteorological Organization (WMO) (2012). Impacts of Megacities on Air Pollution and Climate. Geneva. 141-164.

Yanosky, J. D., Williams, P. L., and MacIntosh, D. L. (2002). A comparison of two direct-reading aerosol monitors with the Federal reference method for $\mathrm{PM}_{2.5}$ in indoor air. Atmos. Environ. 36, 107-113. doi: 10.1016/S1352-2310(01)00422-8

Zuurbier, M., Hoek, G., and Oldenwening, M. (2010). Commuters' exposure to particulate matter air pollution is affected by mode of transport, fuel type, and route. Environ. Health Perspect. 118, 783-789. doi: 10.1289/ehp.0901622

Conflict of Interest Statement: The authors declare that the research was conducted in the absence of any commercial or financial relationships that could be construed as a potential conflict of interest.

Copyright (c) 2016 Franco, Segura and Mura. This is an open-access article distributed under the terms of the Creative Commons Attribution License (CC BY). The use, distribution or reproduction in other forums is permitted, provided the original author(s) or licensor are credited and that the original publication in this journal is cited, in accordance with accepted academic practice. No use, distribution or reproduction is permitted which does not comply with these terms. 